\title{
Tulane
}

Tulane Economics Working Paper Series

\section{The Impact of Fiscal Decentralization on Growth, Inflation, and Inequality in the Americas}

\author{
Antonio N. Bojanic \\ Department of Economics \\ Tulane University \\ abojanic@tulane.edu
}

Working Paper 1610

August 2016

\begin{abstract}
This paper analyzes the impact of fiscal decentralization on economic growth, the inflation rate, and the GINI coefficient in eleven American countries. The findings suggest that the expected positive impacts of this process have been modest, with revenue decentralization being more effective at preventing inflation, and expenditure decentralization showing greater tendency to positively influence growth. The flipside of these findings is that in the full sample of countries revenue decentralization deters growth while expenditure decentralization seems to foster inflation. With regards to the impact on the GINI coefficient, fiscal decentralization seems to be, at best, a marginal, negative influence on income distribution. The main recommendation is that American nations should pause and analyze the reasons why this process of fiscal devolution of responsibilities has not delivered on its promise of greater growth, price stability, and less income inequality.
\end{abstract}

Keywords: Fiscal decentralization, economic growth, inflation, income inequality. JEL codes: E62, H70, O10, O50 
The Impact of Fiscal Decentralization on Growth, Inflation, and Inequality in the Americas

\author{
Antonio N. Bojanic \\ Department of Economics \\ Tulane University \\ abojanic@tulane.edu
}

(504)862-8355 


\begin{abstract}
This paper analyzes the impact of fiscal decentralization on economic growth, the inflation rate, and the GINI coefficient in eleven American countries. The findings suggest that the expected positive impacts of this process have been modest, with revenue decentralization being more effective at preventing inflation, and expenditure decentralization showing greater tendency to positively influence growth. The flipside of these findings is that in the full sample of countries revenue decentralization deters growth while expenditure decentralization seems to foster inflation. With regards to the impact on the GINI coefficient, fiscal decentralization seems to be, at best, a marginal, negative influence on income distribution. The main recommendation is that American nations should pause and analyze the reasons why this process of fiscal devolution of responsibilities has not delivered on its promise of greater growth, price stability, and less income inequality.
\end{abstract}

Keywords: Fiscal decentralization, economic growth, inflation, income inequality

JEL Classification Codes: E62, H70, O10, O50 


\section{Introduction}

For most countries in Latin America, the last three decades have been a period of significant devolution of government activities and functions to sub-national government structures, particularly at the regional, municipal, and local levels. More mature and entrenched democracies with institutions that are increasingly reflecting the demands of specific constituencies, a desire for greater representation of different sub-groups and regions within societies, and the realization that there may be efficiency gains by transferring responsibilities to the areas and communities most directly affected by government interventions, are among the reasons for this trend in decentralization of government activities.

The main subject of this study is fiscal decentralization, which occurs when central governments transfer certain revenue and expenditure responsibilities to sub-national levels of government. Economic research on this topic has for the most part concentrated on how fiscal decentralization impacts governance and economic growth, but more recent efforts have begun analyzing the ways in which it affects poverty, income distribution, and basic fundamental rights, including civil and political rights as well as economic freedom.

Though current research has studied the impact of decentralization on growth extensively, no clear cut conclusions have emerged, particularly when the process of decentralization is analyzed from the perspective of developing nations. Lack of conclusive evidence is even more evident when the matter of decentralization is examined on the ways in which it impacts other variables, such are income distribution and economic stability. This paper aims to help in bridging some of the gaps in current research by analyzing how fiscal decentralization has impacted economic growth, inflation, and income inequality in a region of the world where the issue of decentralization has been at the forefront of structural reforms for the last several decades. 
The rest of the paper is organized as follows. A brief review of the literature on the relationship between fiscal decentralization, growth, economic stability, and inequality is presented in section II. Next, the theoretical arguments underlining how decentralization is expected to impact the principal variables of interest are introduced. The data and methodology are presented in section IV, and the analysis of the empirical results presented in the following section. Section VI summarizes the principal findings and analyzes their policy implications.

\section{Review of the literature}

One of the principal areas of economic research concerning fiscal decentralization deals with how it affects economic growth. Several studies - at the cross country and country-specific levels have analyzed this issue, mostly, but not exclusively, in developed nations. A related theme concerns how decentralization has affected economic stability, and research on this topic is also significant. The most current areas of interest pertain how it impacts poverty, income inequality, and fundamental human liberties. A brief review of some of the most important works on these assorted topics is presented below.

Cross-country studies on how fiscal decentralization impacts economic growth are many. Early important contributions include Davoodi and Zou (1998), working with data for 46 countries and finding that there is a negative correlation between fiscal decentralization and growth in developing nations, but none in developed economies; Martínez-Vázquez and McNab (2003), concluding that while fiscal decentralization may in fact have an impact on growth, the theoretical underpinnings for this relationship remains underdeveloped and hence no definite answer can be provided; Martínez-Vázquez and McNab (2006), finding that when a negative correlation between 
decentralization and growth is established for developed countries, it may be offset by the positive impact of decentralization on macroeconomic stability; and Thornton (2007), working with data for 19 OECD countries and finding that when the measure of fiscal decentralization is limited to the revenues over which sub-national governments have full autonomy, its impact on economic growth is not statistically significant.

More recent works include Rodríguez-Pose and Ezcurra (2011), with a set of 21 OECD countries and finding that there is a negative and significant association between fiscal decentralization and economic growth, despite the inclusion of several control variables and accounting for differences in expenditure preferences by sub-national governments; Amagoh and Amin (2012), concluding that while there may be benefits to be gained from fiscal decentralization, its impact on growth is constrained by a number of factors that are based on the contexts of the societies involved; Baskaran and Feld (2013), also for a set of OECD countries and finding that fiscal decentralization - proxied by standard GFS-style indicators - has a negative and statistically insignificant effect on growth, but with new indicators that account for the degree of sub-national tax autonomy, decentralization has a negative and statistically significant impact on growth; Gemmell, et al. (2013), for a set of OECD countries and finding that spending decentralization has tended to be associated with lower economic growth while revenue decentralization with higher growth; and Blöchliger (2013), finding a positive association between fiscal decentralization and GDP per capita in OECD countries, with the impact of revenue decentralization greater than for spending decentralization. Representative works for individual countries include Xie et al. (1999) for the United States, Yifu Lin and Liu (2000) on China, and Rao (2000) for India.

On the issue of economic stability and how fiscal decentralization affects it, representative works include Neyapti (2004), utilizing a set of countries with varying degrees of inflation and finding 
that revenue decentralization has a negative impact on inflation in higher inflation countries if accompanied by both central bank independence and local accountability, and that in lower inflation countries the negative impact on inflation remains without the need for additional factors. Neyapti (2010), analyzing the topic of fiscal discipline and concluding that for a set of 16 countries expenditure and revenue decentralization reduce budget deficits; Rodden, et al. (2003), analyzing the issue of maintaining fiscal discipline when lower levels of government take responsibility from national authorities, and examining how 'hard' and 'soft' budget constraints impact economic stability in countries with varying degrees of political and institutional development; and Jalil, et al. (2012) focusing on price level stability for 62 countries and finding that decentralization appears to decrease the inflation rate conditional on the level of corruption of political institutions. Country-specific studies include Bodman, et al. (2009), focusing on Australia; Iqbal and Nawaz (2010) on Pakistan; and Okonkwo and Godslove (2015) for Nigeria.

Concerning fiscal decentralization, poverty, and income distribution, significant contributions are Boex, et al. (2006), who in addition to providing a comprehensive survey of the literature on the topic, provide a qualitative set of suggestions for conducting decentralization reforms from a propoor perspective; Sepúlveda and Martínez-Vázquez (2011), with a large data set of countries and finding that fiscal decentralization appears to reduce poverty as long as the share of sub-national expenditures is not greater than one third of total government expenditures, and furthermore helps reducing income inequality only if the general government represents a significant share of the economy; Goerl and Seiferling (2014), utilizing a large data set of countries and finding that the decentralization of government expenditures can help achieve a more equal distribution of income conditional on several factors; and Sacchi and Salotti (2014) for a set of OECD countries and finding that a higher degree of tax decentralization is associated with higher household income 
inequality. At the individual country level, sample of works include Moon (2003) for South Korea, Song (2013) on China, and Cavusoglu and Dincer (2015) focusing on the United States.

A recent area of research concerns analyzing the impact of fiscal decentralization on what can be described as fundamental human rights, term that encompasses civil and political rights as well as economic freedom. Though this line of research is not new in other areas of the social sciences as noted in the early contribution of Kaufman (1969) and in an extensive list of subsequent articles, such are Michels (2011) and Islam (2015) - economics research on the subject is scant. Notable exceptions include Weingast (2009), and Bojanic (2015).

\section{Theoretical foundations between fiscal decentralization, growth, inflation, and income inequality}

Analyzing current research on fiscal decentralization and its impact on a range of indicators leaves the impression that, if anything, there is no certainty as to how decentralization will affect variables such are growth, economic stability, and income inequality. While present empirical work does not provide a clear picture on the ways in which decentralization influences key variables, the current state of research has not prevented economists from hypothesizing on the ways decentralization is expected to affect these very variables. In addition to briefly summarizing the state of the most recent theoretical work, an attempt will be made to direct attention to the issues that are likely to play an important role in understanding how fiscal decentralization affects growth, price stability, and income distribution in the Americas.

Concerning how fiscal decentralization should impact growth, a significant theoretical body of work has already been advanced on the subject (see, for instance, Oates (1993), Brueckner (2005), 
and Martínez-Vázquez and McNab (2006)) and the answer seems to hinge on whether a central authority is better able to utilize fiscal policy to attain long-term growth, or whether a decentralized structure of administering public funds is more capable of delivering outcomes that will translate into growth. While most researchers seem to agree that a positive correlation should be expected - due to better targeting of growth-enhancing infrastructure and greater incentives to save in decentralized regimes - the important qualifier is that the political and institutional context of the economy where decentralization is taking place matters. The inference then, is that though a positive correlation between fiscal decentralization and economic growth is expected, the state of development of an economy will determine whether the decentralization process is able to articulate into policies that generate growth over time.

With regards to the impact of fiscal decentralization on inflation, Martínez-Vázquez and McNab (2006) and Treisman (2000), among others, have developed a theoretical framework for the ways in which decentralization is likely to affect price stability. Without making hypothesis regarding the specific direction in which price stability is likely to be affected by decentralization, their empirical work tends to show that in (mostly) developed economies there is an inverse correlation between inflation and fiscal decentralization - implying that lower inflation levels are more likely in those nations with more decentralized regimes - while the opposite seems to be true in lessdeveloped economies, where decentralization may actually generate higher inflation. From the perspective of nations in the American (Western) hemisphere, an important consideration is that one of the principal reasons for the very high inflation rates these countries have experienced over time is unrestrained government expenditures - with a significant percentage of these expenditures occurring at lower levels of government - which calls attention to the very real concern that 
devolving this specific function to sub-national levels of government may once again foster inflationary pressures.

The theoretical work on how income distribution is affected by fiscal decentralization is not as developed as it is for growth and economic stability. An important exception is Beramendi (2003), proposing a theoretical model that analyzes how decentralization interacts with the politics of redistribution and inequality, and arguing that decentralization per se does not necessarily lead towards higher (or lower) levels of income inequality, but rather that inequality is to a large extent a function of the internal social and political structures of regions. Empirical studies are more numerous and they include, among others, Durham (1999), Sepúlveda and Martínez-Vázquez (2011), and more recently Goerl and Seiferling (2014). From the perspective of this article, if one assumes growth to be a necessary, but not sufficient, condition for eventual greater income equality - following Kuznets' reasoning (1995) - then if fiscal decentralization is expected to have a positive impact on growth, it should also eventually bring greater income equality.

\section{Data and methodology}

With a cross-country study of fiscal decentralization, one of the most significant challenges is how to properly measure the extent of decentralization at various layers of government. A related issue when the study focuses on (mostly) developing nations is finding reliable and credible data. An optimal scenario would be one in which the data set that has been constructed is fully comparable across countries and truly reflects the autonomous decisions of sub-national governments. As can be expected, constructing such a data set is a formidable undertaking because, among other things, it would signify that the degree of autonomy of sub-national governments concerning revenue 
collection and expenditure decisions is known. It would also require a thorough understanding of the nature of the tax system of each nation, particularly as it concerns the structure of revenue sharing among regions, the nature of grants and transfers between the central government and subnational levels of government, and the overall level of political autonomy of regions. Given the difficulties with decentralization indicators that meet all these criteria, the standard practice in the economics literature has been to utilize data collected by the International Monetary Fund reported in its Government Finance Statistics Annual Yearbook (GFS) ${ }^{1}$ - as the primary source for revenue and expenditure data for national (central) and sub-national levels of government. Though the GFS does not report on the nature of government transfers, on whether transfer and grants are under the control of the national or sub-national levels, and furthermore does not currently have disaggregated data for many developing nations, it represents the primary source of data for this study as well.

The standard measures of fiscal decentralization utilized in most decentralization studies are the ratio of total sub-national government revenues to central government revenues and the ratio of total sub-national government expenditures to central government expenditures. These two fiscal decentralization indicators are also utilized here. The GFS data provides information at the consolidated central government level and - for some countries - at the regional, state, and local government levels. Revenues (expenditures) at sub-national levels of government - regional, state, and local governments - were added together in order to come up with a single figure for subnational government revenues (expenditures). Of the 23 countries in the Americas - excluding nations in the Caribbean - GFS reports data disaggregated by central and sub-national levels of government for 11 nations, therefore this study focuses on that sample of American countries for

\footnotetext{
${ }^{1}$ Available at http://www.imf.org/external/pubs/ft/gfs/manual/comp.htm
} 
whom available data exists. ${ }^{2}$ Yearly observations range from 1972 to 2012, though the dates of available data for the eleven countries do not necessarily coincide. ${ }^{3}$ Conditional on: (i) whether the revenue or expenditure decentralization indicators are used as regressors; (ii) on the specific methodology utilized in estimating a regression; and (iii) on dependent variable of the model growth in GDP per capita, inflation rate, or the GINI coefficient - the number of observations varies from a low of 28 to a high of 125 . The end result is an unbalanced panel data set with a maximum of 125 observations for 11 American countries and with observations ranging from 1972 to 2012. Though there are significant gaps in the dataset, it was determined that no averages or linear approximations be used to fill in the gaps in order to let the actual dataset speak for itself.

The three dependent variables utilized here are growth in GDP per capita, ${ }^{4}$ the inflation rate, and the GINI coefficient. Control variables for the set of regressions concerning fiscal decentralization and economic growth are the inflation rate (expressed as a percentage); gross domestic savings (percentage of GDP) and utilized as a proxy for capital formation; openness to international trade $(($ exports + imports)/GDP, as a percentage); remittances (percentage of GDP); foreign direct investment (percentage of GDP); unemployment rate (as a percentage); general government final consumption expenditures (percentage of GDP) and utilized as a proxy for the size of government; and urban population (as a percentage). With the inflation rate as the dependent variable, control variables include GDP per capita in levels (at PPP, in logs); openness to international trade; general government final consumption expenditures; military expenditures (as a percentage of GDP); foreign direct investment; and remittances. Finally, when the GINI coefficient is the dependent variable, control variables are GDP per capita in levels and GDP per capita squared, to account for

\footnotetext{
${ }^{2}$ The 11 countries considered in this study are Bolivia, Brazil, Canada, Chile, Colombia, Costa Rica, El Salvador, Mexico, Paraguay, Peru, and the United States.

${ }^{3}$ The appendix reports the specific time periods of available data for all 11 countries.

${ }^{4}$ Growth in GDP per capita was estimated from GDP per capita based on purchasing power parity.
} 
Kuznets' hypothesis (1955) that growth in income per capita may initially increase inequality but will eventually reduce it; urban population; openness to international trade; ratio of political and civil liberties (ranging from 0.18 to 1.00 ) to account for the extent to which basic human rights affect inequality; ${ }^{5}$ remittances; gross domestic savings; general government final consumption expenditures; inflation rate; and internet users (per 100 people). ${ }^{6}$

The particular specifications for each case conform to previous research on similar topics, but additional control variables have been included - remittances with economic growth and inflation rate specifications; and ratio of political and civil liberties and internet users with the GINI coefficient - when deemed pertinent.

With respect to the model specification, due to the limited amount of information and gaps within an unbalanced panel data set, the likely correlation of observations within and across sections, and the very wide variability of data for the countries in the sample, different regression methodologies were used to address these concerns. Specifically, generalized least squares (GLS) and instrumental variables (IV) regressions accounting for cross-section and within a given crosssection heteroscedasticity (HT) and autocorrelation (AC) were estimated, ${ }^{7}$ as well as GLS with fixed and random cross-section effects, to account, respectively, for omitted variable bias and for the impacts of time-invariant variables. Additionally, generalized method of moments (GMM)

\footnotetext{
5 The source for this combined ratio is Freedom House (http://freedomhouse.org/report-types/freedomworld\#.VY_fWI1RHcw. Freedom House reports two indices of political rights and civil liberties along with a qualitative assessment of the degree of liberty of each nation. Here, the two indices and the qualitative assessment have been combined into a single index of political and civil liberties. It ranges from 0.18 (most free) to 1.00 (least free).

${ }^{6}$ Excepting the ratio of political and civil liberties, the source for all variables is the World Bank: http://data.worldbank.org/data-catalog/world-development-indicators

${ }^{7}$ With both GLS and IVs regressions, the Prais-Winsten Panel Corrected Standard Error (PCSE) Within estimator was estimated in order to correct for serial correlation (cross section and between period correlation)
} 
regressions were estimated to account for the dynamic nature of the relationship between fiscal decentralization, growth, inflation, and income inequality. ${ }^{8}$

\section{Results of the empirical analysis}

Regression results analyzing the impact of fiscal decentralization on GDP per capita, the inflation rate, and the GINI coefficient are reported in sets of two: the first set includes all eleven countries, and the second one excludes Canada and the United States, the two American nations with arguably most developed and stable decentralization regimes in the hemisphere. Excluding these two nations has the benefit of analyzing fiscal decentralization from the perspective of developing American countries only.

The impact of fiscal decentralization on growth is analyzed first. Table 1 presents regression results when all eleven countries are taken into account and the dependent variable is GDP per capita growth.

(Insert Table 1 about here)

The five columns in table 1 report estimates for the five methodologies described in section IV. In the first one, a GLS model accounting for cross section and within a given section heteroscedasticity and autocorrelation is presented. The second and third columns report GLS models with fixed and random cross section effects. Columns four and five report estimates when the variables are instrumented and when the generalized method of moments is used. The instrumental variables and GMM specifications were estimated accounting for both cross section

\footnotetext{
${ }^{8}$ The GMM regressions were estimated utilizing the PCSE method to account for cross section and between period correlation.
} 
and within a given section HT and AC. Additionally, each column contains two regression results: the first one reports estimates when the indicator of fiscal decentralization is revenue based, and the second one when the fiscal decentralization variable is expenditure based.

As is evident from the results reported, the revenue-based fiscal decentralization indicator is consistently shown to have a negative impact on economic growth. The coefficients for this variable in all specifications are negative, of approximately equal size, and statistically significant for GLS and IV regressions accounting for HT and AC and for GLS estimation with random effects. With GMM, the expenditure decentralization indicator is positive and significant, implying that, along with the results with the revenue indicator, fiscal decentralization on the revenue side has not contributed to economic growth - has in fact been a deterrent to growth - but when decentralization occurs with government expenditures, its impact on growth is positive, as predicted by the assumptions made in section III, particularly the one that notes that decentralized expenditure is more likely to be targeted to growth enhancing investment projects.

The behavior of the control variables is also noteworthy. With most, the results conform to expectations regarding how they should impact growth. For instance, savings have the expected positive impact on the dependent variable, regardless of the specification used, while the unemployment rate shows the expected, opposite impact on growth. Openness to international trade is also shown not to be conducive to growth, which conforms to a substantial segment of the economics literature that views the impact of trade with reservations. ${ }^{9}$ A similar result is obtained with FDI, which, as indicated by the GMM estimates when paired with both revenue and expenditure indicators of fiscal decentralization, is shown to have a highly negative and significant

\footnotetext{
${ }^{9}$ A good survey of results addressing some of the reservations regarding the impact of trade on growth is provided by Rodriguez and Rodrik (1999).
} 
impact on growth, underlining concerns that foreign investment may not always generate growth. The impact of remittances is mostly positive and significant, as would be expected, but this variable may have the opposite impact when analyzed from a dynamic perspective. The results for inflation, the size of government, and the extent of urbanization are less clear as they do not show a pattern of consistency across all specifications, hence the difficulty in drawing appropriate inferences.

Table 2 presents regression results analyzing how fiscal decentralization impacts growth when Canada and the US are excluded from the analysis. The specifications and statistical properties of each regression are the same as those in table 1.

(Insert Table 2 about here)

The most visible result is that, unlike what happens when the US and Canada are included in the analysis, fiscal decentralization on the revenue side does not seem to have any impact on growth. The coefficients for this variable are not only statistically insignificant but they also do not show any consistency across all specifications. On the expenditure side, however, the GMM coefficient for this decentralization indicator is positive and significant, confirming that - as was the case with all countries included in the analysis - decentralization of expenditures seems to play an important role in generating economic growth.

With respect to the control variables, for the most part their behavior resembles the situation when all countries are included. Savings and the unemployment rate are consistently shown to have the expected positive and negative impacts on growth, respectively, while openness to trade and FDI show a similar negative incidence on growth. The most important difference lies with the impact of government size: while this variable had ambiguous impact on the dependent variable with all 
countries included, here the results seem to indicate that there is a strong negative incidence of government activities on growth. The GLS estimate for General Government Final Consumption Expenditures with fixed effects and paired with the expenditure decentralization indicator, along the GMM estimates with both revenue and expenditure decentralization indicators, are negative, statistically significant, and of similar size, implying that for developing countries in the American hemisphere, government activities have not been conducive for growth.

Tables 3 and 4 analyze the impact of fiscal decentralization on the inflation rate. The regression methodologies are the same as those utilized when growth was the dependent variable. Table 3 presents estimation results with all countries included in the analysis.

\section{(Insert Table 3 about here)}

The results regarding how fiscal decentralization variables affect the inflation rate are clear: consistently, revenue-based decentralization indicators have a negative and statistically significant (GLS accounting for HT and AC, IV and GMM estimates) impact on the dependent variable while expenditure-based decentralization variables show the opposite effect. In other words, decentralization on the revenue side seems to prevent inflation while on the expenditure side seems to foster it. These results are largely consistent with the assumptions made in section III regarding how fiscal decentralization should impact inflation, namely that when the two developed economies - Canada and the US - are included in the analysis, fiscal decentralization restraints inflationary pressures, as evidenced by the revenue-based decentralization indicators, but when decentralization occurs on the expenditure side, unrestrained expenditures from developing American nations may act in ways that create greater price instability. 
Regarding the control variables, GDP per capita consistently shows to quell inflation, an unsurprising result as evidenced in previous works (Martínez-Vázquez and McNab (2006), for instance), and a similar impact is observed with FDI and Remittances. Government expenditures mostly acts as a deterrent for inflation while for the rest of the variables - openness to international trade and military expenditures - the results are inconclusive.

Table 4 presents results on how the inflation rate is affected by fiscal decentralization when Canada and the US are excluded from the analysis.

(Insert Table 4 about here)

As is evident, the results largely confirm the findings presented in table 3 . With Canada and the US excluded, however, decentralization on the revenue side does not seem to act as strongly in deterring inflation. This is reflected in the fact that only the GMM estimate is negative and significant, whereas with all countries included this result was replicated with other specifications. Furthermore, the decentralization indicator on the expenditure side is consistently positive and significant, confirming that with developing American countries expenditure decentralization may cause inflation, as predicted by the assumptions made on section III.

The behavior of the control variables is slightly better defined with developing American countries only. As expected, GDP per capita is consistently shown to deter inflation, as do government expenditures, FDI, and remittances, demonstrating that the size of government and capital inflows play a positive role in preventing inflation. Reproducing the situation when all countries were included in the analysis, the impact of openness to international trade and military expenditures on the dependent variable is inconclusive. 
The last set of regressions is reported in tables 5 and 6 . Table 5 presents results for the impact of fiscal decentralization on the GINI coefficient when all countries are included in the analysis.

\section{(Insert Table 5 about here)}

The impact of fiscal decentralization on the GINI coefficient, regardless of whether the decentralization indicator is revenue or expenditure based, is slim. There is a single instance - GLS estimations accounting for both $\mathrm{HT}$ and $\mathrm{AC}$ - when the expenditure decentralization indicator is positive and statistically significant at the 10 percent level, implying that decentralization is actually one of the reasons for greater income inequality. With the rest of specifications there is no discernible pattern of behavior, hence the conclusion that decentralization seems to have only a marginal (negative) impact on the dependent variable. The empirical results run counter to the assumption made in section III regarding how fiscal decentralization should affect income inequality. In other words, it seems that even when the Kuznets' prediction comes through - as it does here - greater income equality is not necessarily achieved.

The behavior of the control variables is noteworthy. As Kuznets' hypothesis predicts, GDP per capita initially seems to worsen income distribution (positive and significant coefficient with GMM specification), but eventually seems to decrease it (negative and significant coefficients for GDP per capita squared with GLS and GMM specifications). There is also consistent evidence that greater urbanization and openness to international trade worsen income inequality, and sparse evidence that remittances, savings, and access to internet aggravate it. Inflation, on the other hand, seems to assuage inequality, as reflected in the negative and statistically significant GLS estimates accounting for $\mathrm{HT}$ and $\mathrm{AC}$ when this variable is paired with both revenue and expenditure decentralization indicators. The impact of the ratio of political and civil liberties on the dependent 
variable is inconclusive, as the coefficient for this variable does not follow any discernible pattern, and the size of government seems to worsen income inequality, at least with static regressions.

Table 6 reports regressions estimates for the impact of fiscal decentralization on the GINI coefficient in American countries excluding Canada and the US.

(Insert Table 6 about here)

Though still tenuous, the impact of fiscal decentralization on the dependent variable seems to be a bit clearer when Canada and the US are excluded from the analysis. The expenditure indicator for decentralization is consistently positive and, with GLS accounting for HT and AC and GLS with random effects, statistically significant, confirming that decentralization may actually contribute to greater inequality in developing American nations. On the revenue side, fiscal decentralization seems to have no impact at all on the GINI coefficient. As was the case when all countries were included in the analysis, the empirical results obtained here do not conform to the assumption made in section III regarding how fiscal decentralization should affect income inequality.

With respect to the behavior of the control variables, Kuznets' prediction - though still true in a dynamic framework - is not as clear as with all countries in the sample. Greater urbanization and openness to trade, on the other hand, have the same consistently negative impact on income inequality, inflation shows the same consistent soothing impact on it, and remittances seem to worsen inequality only when paired with the expenditure indicator and in a dynamic framework. Unlike what was observed when all countries were included in the analysis, there is greater consistency in showing that savings do seem to aggravate income inequality, and that access to internet, at least in static regressions, may contribute to improve income distribution. The impact 
of the ratio of political and civil liberties and of government expenditures remain ambiguous, hence no conclusions are made regarding how they affect the dependent variable.

\section{Conclusions and policy implications}

This article analyzes the impact of fiscal decentralization on economic growth, inflation, and income inequality in a sample of American nations. Given that for the last several years most of these countries have undergone a period of gradual decentralization of economic functions to regional levels of government, the results presented here seem timely and relevant.

The main findings are as follows. With respect to the impact of fiscal decentralization on economic growth when all countries are included in the analysis, the revenue-based decentralization indicator is consistently shown to have a negative impact on growth. The expenditure indicator, however, has the opposite effect, implying that while decentralization on the revenue side has not delivered on its promise of greater growth, decentralization on the expenditure seems to have contributed towards this goal. When the same analysis is done excluding Canada and the US, decentralization on the revenue side does not seem to have any impact on growth, but the expenditure decentralization indicator shows the same positive influence obtained with all countries included, confirming that decentralization on the expenditure side seems to be more conducive for growth. The behavior of the control variables is similar regardless of the sample of countries being analyzed. National savings, for instance, is shown to contribute to growth while greater unemployment causes it to diminish. Results with other control variables are also similar but an important difference emerges with government expenditures - a proxy for the size of government 
- in the sample of countries excluding Canada and the US: with developing American nations only, government actions are shown to be a deterrent for growth.

Regarding the impact of fiscal decentralization on the inflation rate and with all countries included, decentralization on the revenue side is consistently shown to prevent inflation while on the expenditure side it seems to foster it. With Canada and the US excluded, however, decentralization on the revenue side seems to prevent inflation only in a dynamic framework, and hence its dissuasive quality is not as compelling as was the case with the full sample of countries. Decentralization on the expenditure side, on the other hand, does show the same impact on inflation, confirming that devolving expenditure functions to sub-national levels of government may generate conditions for greater inflation. The behavior of the control variables in both sets of regressions is similar, with the impact of these variables being slightly better defined in the sample of countries excluding Canada and the US. Consistently, GDP per capita, government expenditures, FDI, and remittances are shown to suppress inflation, while the impact of the rest of the variables is inconclusive.

Finally, regarding the impact of fiscal decentralization on the GINI coefficient and considering the full sample of countries, the results indicate that regardless of whether the decentralization indicator is revenue or expenditure based, the impact on the dependent variable is slim. There is a single instance where the expenditure decentralization indicator is shown to worsen income inequality at the 10 percent level. The lack of consistency of this result with alternative estimates, however, renders this single finding with little value. Since there is no discernible pattern of behavior, the main conclusion is that decentralization seems to have, at best, a marginal impact on the GINI coefficient. 
When Canada and the US are excluded, however, the impact of fiscal decentralization on the dependent variable is a bit clearer. The expenditure decentralization indicator is consistently positive and, with two alternative specifications, statistically significant, implying - and perhaps confirming - that decentralization on the expenditure side may actually contribute to greater inequality, at least in developing American nations. On the revenue side, decentralization does not seem to have any impact on the GINI coefficient, confirming the findings when all countries were included in the analysis.

With respect to the behavior of the control variables, the results are also similar regardless of the sample of countries being analyzed. Kuznets's prediction is generally found to be true, though the findings are clearer with the full sample of countries. Likewise, greater urbanization, openness to international trade, remittances, and savings seem to have a negative impact on income distribution, while inflation acts to mitigate income inequality. An important difference is that when Canada and the US are excluded, internet usage seems to dampen income distribution, at least on a static level, pointing to the importance of access to internet as a tool to reduce inequality. With the rest of the control variables, the results are inconclusive in all cases.

The most important policy implication of the findings presented here is that fiscal decentralization has so far fallen short of expectations regarding its expected impact on growth, price stability, and income distribution. Though its positive impact on helping to achieve price stability is clear with decentralization on the revenue side - particularly when Canada and the US are included in the analysis - fiscal decentralization has yet to play the expected positive role in creating conditions for greater growth, greater price stability, and particularly in helping bridge the income gap in all nations. If anything, it seems that decentralization has caused both greater inflationary pressures - when decentralization occurs on the expenditure side - and inequality, which runs counter to the 
expected impact of a process that was designed to deepen the role of economic actors and improve the lives of people in all regions of a country. In addition to further improving and strengthening the institutions in charge of this process, it seems appropriate and rational that each nation should pause and analyze in detail the reasons why fiscal decentralization has not yet proven to be a catalyst for greater economic growth, greater price stability, and less income inequality throughout the American hemisphere. 


\section{Appendix}

Period of Time Available for Decentralization Indicators

\begin{tabular}{lll} 
Country & Revenues & Expenditures \\
\hline Bolivia & $1985-2007$ & $1985-2001$ \\
Brazil & $2006-2012$ & $2006-2012$ \\
Canada & $1979-1989$ & $2000-2007$ \\
Chile & $1974-2012$ & $2000-2001$ \\
Colombia & $1998-2003$ & $1998-2000$ \\
Costa Rica & $2002-2007$ & $2002-2007$ \\
El Salvador & $2002-2010$ & $\mathrm{NA}$ \\
Mexico & $1972-1998$ & $1990-1997$ \\
Paraguay & $2005-2012$ & $2005-2012$ \\
Peru & $1995-2012$ & $1995-2012$ \\
United States & $1980-2000$ & $1990-2001$ \\
\hline
\end{tabular}

Source: IMF's Government Finance Statistics Annual Yearbook (GFS) 


\section{References}

Amagoh, Francis and Aloysius Ajab Amin (2012). An Examination of the Impacts of Fiscal Decentralization on Economic Growth, International Journal of Business Administration, 3:6, pp. 72-81.

Baskaran, Thushyanthan and Lars P. Feld (2013). Fiscal Decentralization and Economic Growth in OECD Countries - Is There a Relationship? Public Finance Review, 41:4, pp. 421-445.

Beramendi, Pablo (2003). Political Institutions and Income Inequality: The Case of Decentralization, WZB, Markets and Political Economy Working Paper No. SP II 2003-09. Available at SSRN: http://ssrn.com/abstract=473701

Blöchliger, Hansjörg (2013). Decentralization and Economic Growth - Part 1: How Fiscal Federalism Affects Long-Term Development, OECD Working Papers on Fiscal Federalism, No. 14, OECD Publishing, Paris. DOI: http://dx.doi.org/10.1787/5k4559gx1q8r-en

Bodman, Philip, Harry Campbell, Kelly-Ana Heaton, and Andrew Hodge (2009). Fiscal Decentralisation, Macroeconomic Conditions and Economic Growth in Australia, Macroeconomics Research Group Working Paper. Available at: www.uq.edu.au/economics/mrg/2609.pdf

Boex, Jameson, Eunice Heredia-Ortíz, Jorge Martínez-Vázquez, Andrey Timofeev, and Guevera Yao (2006). Fighting Poverty through Fiscal Decentralization, United States Agency for International Development (USAID) Report, Washington, DC. Available at USAID: http://pdf.usaid.gov/pdf_docs/PNADH105.pdf

Bojanic, Antonio N. (2015). Fiscal Decentralization, Economic Freedom, and Political and Civil Liberties in the Americas. Working paper.

Brueckner, Jan K. (2005). Fiscal Federalism and Economic Growth, CESifo working papers, No. 1601. Available at: www.econstor.edu/bitstream/10419/19065/1/cesifo1_wp1601.pdf

Cavusoglu, Tarkan and Oguzhan Dincer (2015). Does Decentralization Reduce Income Inequality? Only in Rich States, Southern Economic Journal, 82:1, pp. 285-306.

Davoodi, Hamid and Heng-fu Zou (1998). Fiscal Decentralization and Economic Growth: A Cross-Country Study, Journal of Urban Economics, 43, pp. 244-257.

Durham, J. Benson (1999). Econometrics of Income Distribution: Toward More Comprehensive Specification of Institutional Correlates, Comparative Economic Studies, 41:1, pp. 43-74.

Gemmell, Norman, Richard Kneller, and Ismael Sanz (2013). Fiscal Decentralization and Economic Growth: Spending versus Revenue Decentralization, Economic Inquiry, 51:4, pp. 19151931.

Goerl, Caroline-Antonia and Mike Seiferling (2014). Income Inequality, Fiscal Decentralization and Transfer Dependency. International Monetary Fund (IMF) Working Paper 14/64, Washington, DC. Available at IMF: http://www.imf.org/external/pubs/ft/wp/2014/wp1464.pdf 
Iqbal, Nasir and Saima Nawaz (2010). Fiscal Decentralization and Macroeconomic Stability: Theory and Evidence from Pakistan, Munich Personal RePEc Archive (MPRA). Available at: http://mpra.ub.uni-muenchen.de/27184/

Islam, Fakhrul (2015). The Role of Local Self-Government Institution for Deepening Democracy at the Grass-Root Level in Bangladesh, Journal of Public Administration and Policy Research, 7:2, pp. 29-38.

Jalil, Ahmad Z., Mukaramah Harun, and Siti Hadijah Che Mat (2012). Macroeconomic Instability and Fiscal Decentralization: An Empirical Analysis, Prague Economic Papers, 2, pp. 150-165.

Kaufman, Herbert (1969). Admnistrative Decentralization and Political Power, Public Administration Review, 29:1, pp. 3-15.

Kuznets, Simon (1955). Economic Growth and Income Inequality, American Economic Review, 45, pp. 1-28.

Martínez-Vázquez, Jorge and Robert M. McNab (2003). Fiscal Decentralization and Economic Growth, World Development, 31:9, pp. 1597-1616.

Martínez-Vázquez, Jorge and Robert M. McNab (2006). Fiscal Decentralization, Macrostability, and Growth, Hacienda Pública Española / Revista de Economía Pública, 179:4, pp. 25-49.

Michels, Ank (2011). Innovations in Democratic Governance: How does Citizen Participation Contribute to a Better Democracy? International Review of Administrative Sciences, 77:2, pp. 275-293.

Moon, Hyungpyo (2003). Regional Inequality and Fiscal Decentralization in Korea: Evaluation and Policy Implications, Korea Development Institute. Available at: www.kdi.re.kr/upload/7050/IV_HyungpyoMoon.pdf

Neyapti, Bilin (2004). Fiscal Decentralization, Central Bank Independence and Inflation: A Panel Investigation, Economic Letters, 82:2, pp. 227-230.

Neyapti, Bilin (2010). Fiscal Decentralization and Deficits: International Evidence, European Journal of Political Economy, 26, pp. 155-166.

Oates, Wallace (1993). Fiscal Decentralization and Economic Development, National Tax Journal, 46, pp. 237-243.

Okonkwo, Osmond N., and Egbulonu K. Godslove (2015). Fiscal Decentralization and Nigerian Macroeconomic Performance and Economic Stability, International Journal of Economics and Finance, 7:2, pp. 113-121.

Rao, M. Govinda (2000). Fiscal Decentralization in Indian Federalism, Institute for Social and Economic Change, Bangalore. Available at: https://www.imf.org/external/pubs/ft/seminar/2000/fiscal/rao.pdf

Rodden, Jonathan, Gunnar Eskeland, and Jennie Litvack (2003). Fiscal Decentralization and the Challenge of Hard Budget Constraints. Cambridge and London: MIT Press. 
Rodríguez, Francisco and Dani Rodrik (1999). Trade Policy and Economic Growth: A Skeptic's Guide to Cross-National Evidence, NBER Working Paper No. 7081. Available at: www.nber.org/papers/w7081

Rodríguez-Pose, Andrés and Roberto Ezcurra (2011). Is Fiscal Decentralization Harmful for Economic Growth? Evidence from the OECD Countries, Journal of Economic Geography, 11:4, pp. 619-643.

Sacchi, Agnese and Simone Salotti (2014). The Effects of Fiscal Decentralization on Household Income Inequality: Some Empirical Evidence, Spatial Economic Analysis, 9:2, pp. 202-222.

Sepúlveda, F., Cristian and Jorge Martínez-Vázquez (2011). The Consequences of Fiscal Decentralization on Poverty and Income Inequality, Environment and Planning C: Government and Policy, 29:2, pp. 321-343.

Song, Yang (2013). Rising Chinese Regional Income Inequality: The Role of Fiscal Decentralization, China Economic Review, 27, pp. 294-309.

Thornton, John (2007). Fiscal Decentralization and Economic Growth Revisited, Journal of Urban Economics, 61:1, pp. 64-70.

Treisman, Daniel (2000). Decentralization and Inflation: Commitment, Collective Action, or Continuity? American Political Science Review, 94:4, pp. 837-857.

Weingast, Barry, R. (2009). Second Generation Fiscal Federalism: The Implications of Fiscal Incentives, Journal of Urban Economics, 65, pp. 279-293.

Xie, Danyang, Heng-fu Zou, and Hamid Davoodi (1999). Fiscal Decentralization and Economic Growth in the United States, Journal of Urban Economics, 45, pp. 228-239.

Yifu Lin, Justin and Zhiqiang Liu (2000). Fiscal Decentralization and Economic Growth in China, Economic Development and Cultural Change, 49:1, pp. 1-21. 
Table 1: Fiscal Decentralization and GDP per Capita

Dependent variable: Growth in GDP per Capita

All Countries

\begin{tabular}{|c|c|c|c|c|c|c|c|c|c|c|}
\hline \multirow[b]{2}{*}{ Revenue decentralization (\%) } & \multicolumn{2}{|c|}{$\begin{array}{l}\text { GLS accounting for } \\
\text { cross-section and } \\
\text { within a given cross- } \\
\text { section } \mathrm{HT}, \mathrm{AC} \text { (no } \\
\text { effects specification) }\end{array}$} & \multicolumn{2}{|c|}{$\begin{array}{l}\text { GLS with fixed, cross- } \\
\text { section effects and no } \\
\text { weights }\end{array}$} & \multicolumn{2}{|c|}{$\begin{array}{l}\text { GLS with random, } \\
\text { cross-section effects } \\
\text { and no weights }\end{array}$} & \multicolumn{2}{|c|}{$\begin{array}{l}\text { IV accounting for } \\
\text { cross-section and } \\
\text { within a given cross- } \\
\text { section } \mathrm{HT}, \mathrm{AC} \text { (no } \\
\text { effects specification) }\end{array}$} & \multicolumn{2}{|c|}{$\begin{array}{c}\text { Generalized Method of } \\
\text { Moments }\end{array}$} \\
\hline & $-0.085^{* *}$ & & -0.028 & & $-0.100 *$ & & $-0.094^{*}$ & & -0.002 & \\
\hline & $(0.032)$ & & $(0.127)$ & & $(0.059)$ & & $(0.053)$ & & $(0.053)$ & \\
\hline \multirow[t]{2}{*}{ Expenditure decentralization (\%) } & & -0.022 & & 0.221 & & -0.017 & & -0.046 & & $0.278^{* * *}$ \\
\hline & & $(0.027)$ & & $(0.174)$ & & (0.059) & & $(0.086)$ & & $(0.039)$ \\
\hline \multirow[t]{2}{*}{ Inflation rate (\%) } & 0.001 & -0.006 & 0.001 & -0.007 & 0.001 & 0.003 & -0.014 & -0.329 & -0.003 & $0.125^{* * *}$ \\
\hline & $(0.000)$ & $(0.015)$ & $(0.000)$ & $(0.025)$ & $(0.000)$ & $(0.022)$ & $(0.013)$ & $(1.510)$ & $(0.004)$ & $(0.039)$ \\
\hline \multirow[t]{2}{*}{ Gross domestic savings (\% of GDP) } & $0.408 * * *$ & 0.100 & $0.390 * *$ & 0.190 & $0.345^{* *}$ & 0.091 & $0.372 * * *$ & 0.059 & $0.692 * * *$ & $0.458 * * *$ \\
\hline & $(0.067)$ & (0.125) & $(0.169)$ & $(0.305)$ & $(0.137)$ & $(0.227)$ & $(0.121)$ & $(0.445)$ & $(0.091)$ & $(0.083)$ \\
\hline \multirow[t]{2}{*}{ Openness to international trade $((X+M) / G D P)(\%)$} & $-0.080^{* *}$ & 0.033 & -0.170 & -0.179 & -0.073 & 0.027 & -0.053 & 0.016 & $-0.377 * * *$ & $-0.342 * * *$ \\
\hline & $(0.025)$ & $(0.023)$ & $(0.113)$ & $(0.170)$ & $(0.045)$ & $(0.051)$ & $(0.043)$ & $(0.088)$ & $(0.052)$ & $(0.047)$ \\
\hline \multirow[t]{2}{*}{ Remittances (\% of GDP) } & $0.399 * * *$ & -0.510 & 0.604 & -0.133 & $0.252^{*}$ & -0.691 & $0.342^{* *}$ & 1.639 & $0.767^{* * *}$ & $-2.226 * * *$ \\
\hline & $(0.097)$ & $(0.611)$ & $(0.530)$ & $(2.166)$ & $(0.197)$ & $(0.883)$ & $(0.165)$ & $(3.406)$ & $(0.315)$ & $(0.593)$ \\
\hline \multirow[t]{2}{*}{ Foreign direct investment ( $\%$ of GDP) } & 0.062 & 0.099 & -0.138 & -0.514 & $0.029)$ & 0.054 & -0.184 & -0.196 & $-0.331 * * *$ & $-0.517 * * *$ \\
\hline & $(0.102)$ & $(0.125)$ & $(0.220)$ & $(0.410)$ & $(0.171)$ & $(0.225)$ & $(0.155)$ & $(0.346)$ & $(0.119)$ & $(0.102)$ \\
\hline \multirow[t]{2}{*}{ Unemployment rate (\% of total labor force) } & $-0.250 * *$ & -0.121 & $-0.457 * *$ & $-0.495^{*}$ & $-0.314 * *$ & -0.256 & $-0.219 *$ & 0.147 & $-0.719 * * *$ & $-0.605 * * *$ \\
\hline & $(0.081)$ & (0.098) & $(0.180)$ & $(0.265)$ & $(0.121)$ & $(0.161)$ & $(0.130)$ & $(1.411)$ & $(0.036)$ & $(0.040)$ \\
\hline \multirow[t]{2}{*}{ General gov final consumption exp (\% of GDP) } & $0.204^{*}$ & -0.181 & -0.457 & $-1.204^{*}$ & 0.209 & -0.232 & $0.354^{* *}$ & 0.321 & $-0.923 * * *$ & $-1.115^{* * *}$ \\
\hline & $(0.107)$ & $(0.132)$ & $(0.421)$ & $(0.618)$ & $(0.251)$ & $(0.266)$ & $(0.169$ & $(0.790)$ & $(0.137)$ & $(0.194)$ \\
\hline \multirow[t]{2}{*}{ Urban population (\% of total population) } & $-0.101^{* *}$ & $0.155^{*}$ & -0.085 & 0.103 & -0.051 & 0.131 & -0.089 & 0.060 & -0.157 & $0.348 * * *$ \\
\hline & $(0.049)$ & $(0.081)$ & $(0.369)$ & $(0.655)$ & $(0.083)$ & $(0.141)$ & $(0.077)$ & $(0.200)$ & $(0.105)$ & $(0.126)$ \\
\hline Observations & 125 & 82 & 125 & 82 & 125 & 82 & 113 & 72 & 103 & 62 \\
\hline Adj $R^{2}$ & 0.35 & 0.34 & 0.14 & 0.10 & 0.14 & 0.09 & 0.33 & - & - & - \\
\hline
\end{tabular}


All regressions include an intercept term (not shown in table)

GMM specifications include a one-period lagged dependent variable as regressor (not shown in table)

Standard errors in parentheses

${ }^{*}$ significant at $10 \%$; ${ }^{* *}$ significant at $5 \%$; ${ }^{* *}$ significant at $1 \%$ 
Table 2: Fiscal Decentralization and GDP per Capita

Dependent variable: Growth in GDP per Capita

American countries excluding Canada and the US

\begin{tabular}{|c|c|c|c|c|c|c|c|c|c|c|}
\hline \multirow[b]{2}{*}{ Revenue decentralization (\%) } & \multicolumn{2}{|c|}{$\begin{array}{l}\text { GLS accounting for } \\
\text { cross-section and } \\
\text { within a given cross- } \\
\text { section HT, AC (no } \\
\text { effects specification) }\end{array}$} & \multicolumn{2}{|c|}{$\begin{array}{l}\text { GLS with fixed, cross- } \\
\text { section effects and no } \\
\text { weights }\end{array}$} & \multicolumn{2}{|c|}{$\begin{array}{l}\text { GLS with random, } \\
\text { cross-section effects } \\
\text { and no weights }\end{array}$} & \multicolumn{2}{|c|}{$\begin{array}{l}\text { IV accounting for } \\
\text { cross-section and } \\
\text { within a given cross- } \\
\text { section HT, AC (no } \\
\text { effects specification) }\end{array}$} & \multicolumn{2}{|c|}{$\begin{array}{c}\text { Generalized Method of } \\
\text { Moments }\end{array}$} \\
\hline & -0.040 & & 0.006 & & -0.093 & & 0.003 & & -0.017 & \\
\hline & $(0.039)$ & & $(0.142)$ & & $(0.071)$ & & $(0.121)$ & & $(0.124)$ & \\
\hline \multirow[t]{2}{*}{ Expenditure decentralization (\%) } & & 0.047 & & 0.250 & & -0.015 & & 0.041 & & $0.333^{* * *}$ \\
\hline & & $(0.075)$ & & $(0.206)$ & & $(0.075)$ & & $(0.248)$ & & $(0.064)$ \\
\hline \multirow[t]{2}{*}{ Inflation rate $(\%)$} & 0.001 & -0.010 & 0.001 & -0.008 & 0.001 & 0.001 & -0.014 & -0.586 & 0.008 & 0.070 \\
\hline & $(0.000)$ & $(0.016)$ & $(0.000)$ & $(0.028)$ & $(0.000)$ & $(0.026)$ & $(0.014)$ & $(2.351)$ & $(0.018)$ & (0.059) \\
\hline \multirow[t]{2}{*}{ Gross domestic savings (\% of GDP) } & $0.248^{* * *}$ & 0.065 & 0.265 & 0.098 & 0.246 & 0.061 & 0.125 & 0.174 & $0.764 * * *$ & $0.381 *$ \\
\hline & $(0.080)$ & $(0.164)$ & $(0.202)$ & $(0.357)$ & $(0.157)$ & $(0.244)$ & $(0.286)$ & $(0.858)$ & $(0.201)$ & $(0.210)$ \\
\hline \multirow[t]{2}{*}{ Openness to international trade $((X+M) / G D P)(\%)$} & -0.031 & 0.064 & -0.148 & -0.178 & -0.066 & 0.011 & 0.021 & 0.028 & $-0.455^{* * *}$ & $-0.289 * *$ \\
\hline & $(0.029)$ & $(0.053)$ & $(0.125)$ & $(0.190)$ & $(0.051)$ & $(0.060)$ & $(0.093)$ & $(0.157)$ & $(0.111)$ & $(0.121)$ \\
\hline \multirow[t]{2}{*}{ Remittances (\% of GDP) } & $0.211^{*}$ & -1.026 & 0.380 & -0.464 & 0.217 & -0.636 & 0.010 & -0.187 & 0.945 & $-1.951^{*}$ \\
\hline & $(0.111)$ & $(0.652)$ & $(0.597)$ & $(2.470)$ & $(0.222)$ & (1.012) & $(0.378)$ & (3.106) & $(0.602)$ & (1.159) \\
\hline \multirow[t]{2}{*}{ Foreign direct investment (\% of GDP) } & 0.035 & 0.074 & -0.233 & -0.551 & 0.140 & 0.139 & -0.441 & -0.502 & $-0.500 * *$ & $-0.735 * * *$ \\
\hline & $(0.119)$ & $(0.186)$ & $(0.248)$ & $(0.494)$ & $(0.188)$ & $(0.245)$ & $(0.313)$ & $(0.789)$ & $(0.221)$ & $(0.157)$ \\
\hline \multirow[t]{2}{*}{ Unemployment rate (\% of total labor force) } & $-0.227^{* *}$ & -0.142 & $-0.463 * *$ & -0.460 & $-0.300 * *$ & -0.250 & $-0.258^{*}$ & 0.001 & $-0.856 * * *$ & $-0.621 * * *$ \\
\hline & $(0.083)$ & $(0.128)$ & $(0.198)$ & $(0.304)$ & $(0.126)$ & (0.192) & $(0.138)$ & $(1.017)$ & $(0.131)$ & $(0.062)$ \\
\hline \multirow[t]{2}{*}{ General gov final consumption exp ( $\%$ of GDP) } & 0.028 & -0.321 & -0.782 & $-1.549 *$ & 0.157 & -0.227 & -0.024 & 0.329 & $-1.187^{* *}$ & $-1.145^{* *}$ \\
\hline & $(0.127)$ & $(0.197)$ & $(0.525)$ & $(0.785)$ & $(0.277)$ & $(0.286)$ & $(0.431)$ & $(1.353)$ & $(0.412)$ & $(0.404)$ \\
\hline \multirow[t]{2}{*}{ Urban population (\% of total population) } & -0.003 & 0.153 & 0.124 & 0.354 & -0.013 & 0.140 & 0.058 & -0.122 & 0.134 & 0.358 \\
\hline & $(0.057)$ & $(0.104)$ & $(0.438)$ & $(0.783)$ & $(0.095)$ & (0.146) & (0.176) & $(0.826)$ & $(0.233)$ & $(0.222)$ \\
\hline Observations & 104 & 67 & 104 & 67 & 104 & 67 & 93 & 59 & 84 & 51 \\
\hline $\operatorname{Adj} R^{2}$ & 0.32 & 0.29 & 0.12 & 0.08 & 0.15 & 0.07 & 0.27 & - & - & - \\
\hline
\end{tabular}


All regressions include an intercept term (not shown in table)

GMM specifications include a one-period lagged dependent variable as regressor (not shown in table)

Standard errors in parentheses

${ }^{*}$ significant at $10 \% ;{ }^{* *}$ significant at $5 \% ;{ }^{* *}$ significant at $1 \%$ 
Table 3: Fiscal Decentralization and Inflation

Dependent variable: Inflation Rate

All Countries

\begin{tabular}{|c|c|c|c|c|c|c|c|c|c|c|}
\hline \multirow[b]{2}{*}{ Revenue decentralization (\%) } & \multicolumn{2}{|c|}{$\begin{array}{l}\text { GLS accounting for } \\
\text { cross-section and } \\
\text { within a given cross- } \\
\text { section } \mathrm{HT}, \mathrm{AC} \text { (no } \\
\text { effects specification) }\end{array}$} & \multicolumn{2}{|c|}{$\begin{array}{l}\text { GLS with fixed, cross- } \\
\text { section effects and no } \\
\text { weights }\end{array}$} & \multicolumn{2}{|c|}{$\begin{array}{l}\text { GLS with random, } \\
\text { cross-section effects } \\
\text { and no weights }\end{array}$} & \multicolumn{2}{|c|}{$\begin{array}{l}\text { IV accounting for } \\
\text { cross-section and } \\
\text { within a given cross- } \\
\text { section } \mathrm{HT}, \mathrm{AC} \text { (no } \\
\text { effects specification) }\end{array}$} & \multicolumn{2}{|c|}{$\begin{array}{c}\text { Generalized Method of } \\
\text { Moments }\end{array}$} \\
\hline & $-0.126 * * *$ & & -0.082 & & 0.136 & & $-0.143 * * *$ & & $-0.174 * *$ & \\
\hline & $(0.032)$ & & $(0.266)$ & & $(0.172)$ & & $(0.034)$ & & $(0.069)$ & \\
\hline \multirow[t]{2}{*}{ Expenditure decentralization (\%) } & & $0.175^{* *}$ & & 0.052 & & 0.099 & & $0.388^{* *}$ & & $0.380 * *$ \\
\hline & & $(0.070)$ & & $(0.155)$ & & $(0.147)$ & & $(0.139)$ & & $(0.164)$ \\
\hline \multirow[t]{2}{*}{ GDP per capita (at PPP, in logs) } & $-2.875 * * *$ & $-5.975 * * *$ & $-10.798^{*}$ & -4.854 & $-7.119 *$ & -4.795 & $-2.438 * * *$ & $-8.827 * * *$ & $-7.483^{* * *}$ & $-9.561 * *$ \\
\hline & $(0.537)$ & $(0.997)$ & $(6.210)$ & $(5.537)$ & $(3.647)$ & $(4.504)$ & $(0.565)$ & $(1.897)$ & $(2.122)$ & (3.957) \\
\hline \multirow[t]{2}{*}{ Openness to international trade $((X+M) / G D P)(\%)$} & $-0.075 * * *$ & $0.047^{* *}$ & 0.135 & 0.110 & -0.094 & 0.064 & $-0.058^{* *}$ & $0.081 * *$ & $0.225^{* * *}$ & $0.201 * *$ \\
\hline & $(0.024)$ & $(0.022)$ & $(0.217)$ & $(0.134)$ & $(0.114)$ & $(0.111)$ & $(0.028)$ & $(0.036)$ & $(0.066)$ & $(0.074)$ \\
\hline \multirow[t]{2}{*}{ General gov final consumption exp ( $\%$ of GDP) } & 0.160 & -0.127 & -1.624 & $-1.514^{* *}$ & $-1.707^{* *}$ & $-1.377^{* *}$ & $0.424 * *$ & -0.109 & -0.264 & $-2.409 * * *$ \\
\hline & (0.119) & $(0.130)$ & $(1.118)$ & $(0.636)$ & $(0.809)$ & $(0.590)$ & $(0.152)$ & $(0.179)$ & $(0.240)$ & $(0.370)$ \\
\hline \multirow[t]{2}{*}{ Military expenditures (\% of GDP) } & $-0.890 * * *$ & $-0.651 * *$ & -0.267 & 1.900 & -0.575 & 1.596 & $-0.715^{* *}$ & -0.433 & -0.038 & $4.713^{* * *}$ \\
\hline & $(0.288)$ & $(0.287)$ & (3.270) & (1.938) & (1.979) & $(1.753)$ & $(0.295)$ & $(0.465)$ & $(1.126)$ & $(1.065)$ \\
\hline \multirow[t]{2}{*}{ Foreign direct investment ( $\%$ of GDP) } & $-0.417^{* * *}$ & $-0.780 * * *$ & -0.171 & -0.098 & -0.611 & -0.213 & $-0.460 * *$ & $-1.302 * * *$ & -0.109 & $-0.659 * *$ \\
\hline & $(0.122)$ & (0.183) & $(0.532)$ & $(0.359)$ & $(0.451)$ & $(0.340)$ & $(0.167)$ & $(0.320)$ & $(0.168)$ & $(0.258)$ \\
\hline \multirow[t]{2}{*}{ Remittances (\% of GDP) } & $-0.433 * * *$ & $-1.470 * *$ & 0.444 & -1.823 & -0.449 & -1.763 & $-0.367 * * *$ & 0.013 & 0.117 & -0.856 \\
\hline & $(0.064)$ & $(0.712)$ & $(1.227)$ & $(1.903)$ & $(0.562)$ & $(1.831)$ & $(0.066)$ & $(1.142)$ & $(0.379)$ & $(1.893)$ \\
\hline Observations & 104 & 74 & 104 & 74 & 104 & 74 & 94 & 65 & 85 & 56 \\
\hline Adj $R^{2}$ & 0.49 & 0.59 & 0.42 & 0.70 & 0.07 & 0.14 & 0.44 & 0.56 & - & - \\
\hline
\end{tabular}

All regressions include an intercept term (not shown in table)

GMM specifications include a one-period lagged dependent variable as regressor (not shown in table)

Standard errors in parentheses

${ }^{*}$ significant at $10 \% ;{ }^{* *}$ significant at $5 \% ;{ }^{* * *}$ significant at $1 \%$ 
Table 4: Fiscal Decentralization and Inflation

Dependent variable: Inflation Rate

American countries excluding Canada and the US

\begin{tabular}{|c|c|c|c|c|c|c|c|c|c|c|}
\hline \multirow[b]{2}{*}{ Revenue decentralization (\%) } & \multicolumn{2}{|c|}{$\begin{array}{l}\text { GLS accounting for } \\
\text { cross-section and } \\
\text { within a given cross- } \\
\text { section HT, AC (no } \\
\text { effects specification) }\end{array}$} & \multicolumn{2}{|c|}{$\begin{array}{l}\text { GLS with fixed, cross- } \\
\text { section effects and no } \\
\text { weights }\end{array}$} & \multicolumn{2}{|c|}{$\begin{array}{l}\text { GLS with random, } \\
\text { cross-section effects } \\
\text { and no weights }\end{array}$} & \multicolumn{2}{|c|}{$\begin{array}{l}\text { IV accounting for } \\
\text { cross-section and } \\
\text { within a given cross- } \\
\text { section HT, AC (no } \\
\text { effects specification) }\end{array}$} & \multicolumn{2}{|c|}{$\begin{array}{c}\text { Generalized Method of } \\
\text { Moments }\end{array}$} \\
\hline & 0.037 & & -0.090 & & -0.062 & & -0.042 & & $-0.402 * * *$ & \\
\hline & $(0.056)$ & & $(0.291)$ & & $(0.158)$ & & $(0.085)$ & & $(0.123)$ & \\
\hline \multirow[t]{2}{*}{ Expenditure decentralization (\%) } & & $0.490 * * *$ & & 0.102 & & $0.588 * * *$ & & 0.318 & & $0.337^{*}$ \\
\hline & & $(0.092)$ & & $(0.189)$ & & $(0.111)$ & & $(0.419)$ & & $(0.187)$ \\
\hline \multirow[t]{2}{*}{ GDP per capita (at PPP, in logs) } & -0.559 & $-3.634 * * *$ & -12.218 & -5.580 & -1.756 & -2.577 & -1.123 & -4.764 & $-15.627^{* *}$ & $-11.576^{* *}$ \\
\hline & $(0.820)$ & $(0.960)$ & (7.965) & (6.495) & $(2.479)$ & $(2.001)$ & $(1.090)$ & (3.223) & (3.503) & $(3.855)$ \\
\hline \multirow[t]{2}{*}{ Openness to international trade $((X+M) / G D P)(\%)$} & $-0.058 * *$ & $0.172 * * *$ & 0.136 & 0.122 & $-0.186^{* *}$ & $0.166^{* * *}$ & -0.049 & 0.061 & $0.210 * *$ & $0.250 * * *$ \\
\hline & $(0.027)$ & $(0.040)$ & $(0.233)$ & $(0.153)$ & $(0.068)$ & $(0.054)$ & $(0.032)$ & $(0.202)$ & $(0.088)$ & $(0.043)$ \\
\hline \multirow[t]{2}{*}{ General gov final consumption exp (\% of GDP) } & $-0.571 *$ & $-0.891 * * *$ & -1.588 & $-1.622 * *$ & -0.933 & $-1.084 * * *$ & -0.033 & 0.176 & 0.660 & $-2.308^{* * *}$ \\
\hline & $(0.287)$ & $(0.238)$ & $(1.225)$ & $(0.744)$ & (0.689) & $(0.361)$ & $(0.374)$ & $(1.170)$ & $(0.635)$ & $(0.319)$ \\
\hline \multirow[t]{2}{*}{ Military expenditures (\% of GDP) } & $1.501^{*}$ & $3.946 * * *$ & -2.041 & 2.919 & -2.091 & $3.627^{* *}$ & 0.921 & 6.162 & $-12.639 * *$ & $5.084 * * *$ \\
\hline & $(0.855)$ & $(1.558)$ & $(6.513)$ & (3.795) & $(1.865)$ & $(1.751)$ & (1.448) & $(5.783)$ & $(3.895)$ & $(0.799)$ \\
\hline \multirow[t]{2}{*}{ Foreign direct investment (\% of GDP) } & $-0.770 * * *$ & $-1.205^{* * *}$ & -0.129 & -0.174 & $-1.197^{* *}$ & $-1.707 * * *$ & $-0.836 * * *$ & $-1.658^{* *}$ & 0.507 & $-0.409 *$ \\
\hline & $(0.134)$ & $(0.181)$ & $(0.592)$ & $(0.436)$ & $(0.467)$ & $(0.297)$ & $(0.276)$ & $(0.766)$ & $(0.285)$ & $(0.205)$ \\
\hline \multirow[t]{2}{*}{ Remittances (\% of GDP) } & $-0.316 * * *$ & $-2.303 * * *$ & 0.400 & -1.628 & $-0.713^{* *}$ & -1.698 & $-0.298 * *$ & 3.121 & 0.190 & $-3.237 * *$ \\
\hline & $(0.080)$ & $(0.716)$ & $(1.327)$ & (2.205) & $(0.264)$ & (1.196) & (0.109) & $(5.935)$ & $(0.451)$ & $(1.335)$ \\
\hline Observations & 91 & 59 & 91 & 59 & 91 & 59 & 82 & 52 & 74 & 45 \\
\hline Adj $R^{2}$ & 0.30 & 0.50 & 0.39 & 0.64 & 0.15 & 0.36 & 0.16 & - & - & - \\
\hline
\end{tabular}

All regressions include an intercept term (not shown in table)

GMM specifications include a one-period lagged dependent variable as regressor (not shown in table)

Standard errors in parentheses

${ }^{*}$ significant at $10 \% ;{ }^{* *}$ significant at $5 \% ;{ }^{* *}$ significant at $1 \%$ 
Table 5: Fiscal Decentralization and Income Distribution

Dependent variable: GINI Coefficient

All Countries

\begin{tabular}{|c|c|c|c|c|c|c|c|c|c|c|}
\hline \multirow[b]{2}{*}{ Revenue decentralization (\%) } & \multicolumn{2}{|c|}{$\begin{array}{l}\text { GLS accounting for } \\
\text { cross-section and } \\
\text { within a given cross- } \\
\text { section HT, AC (no } \\
\text { effects specification) }\end{array}$} & \multicolumn{2}{|c|}{$\begin{array}{l}\text { GLS with fixed, cross- } \\
\text { section effects and no } \\
\text { weights }\end{array}$} & \multicolumn{2}{|c|}{$\begin{array}{l}\text { GLS with random, cross- } \\
\text { section effects and no } \\
\text { weights }\end{array}$} & \multicolumn{2}{|c|}{$\begin{array}{l}\text { IV accounting for cross- } \\
\text { section and within a } \\
\text { given cross-section HT, } \\
\text { AC (no effects } \\
\text { specification) }\end{array}$} & \multicolumn{2}{|c|}{$\begin{array}{l}\text { Generalized Method of } \\
\text { Moments }\end{array}$} \\
\hline & -0.009 & & 0.047 & & 0.015 & & 0.028 & & 0.033 & \\
\hline & $(0.035)$ & & $(0.15)$ & & $(0.07)$ & & $(0.08)$ & & $(0.11)$ & \\
\hline \multirow[t]{2}{*}{ Expenditure decentralization (\%) } & & $0.094^{*}$ & & -0.100 & & 0.056 & & 0.127 & & -0.134 \\
\hline & & $(0.05)$ & & $(0.33)$ & & $(0.08)$ & & $(0.13)$ & & $(0.21)$ \\
\hline \multirow[t]{2}{*}{ GDP per capita (at PPP, in logs) } & -13.779 & 42.906 & -84.157 & -119.85 & -32.201 & 34.714 & -42.012 & 40.755 & -38.130 & $96.055^{* *}$ \\
\hline & $(20.24)$ & (26.95) & $(65.09)$ & $(121.08)$ & $(35.35)$ & (31.99) & $(27.43)$ & (43.29) & $(59.31)$ & $(42.68)$ \\
\hline \multirow[t]{2}{*}{ GDP per capita squared (at PPP, in logs) } & 0.176 & $-2.941 * *$ & 3.826 & 6.558 & 1.229 & -2.461 & 1.736 & -2.683 & 0.939 & $-6.172 * * *$ \\
\hline & (1.11) & $(1.45)$ & (3.68) & $(7.60)$ & $(1.91)$ & $(1.72)$ & $(1.50)$ & $(2.31)$ & $(3.23)$ & (2.29) \\
\hline \multirow[t]{2}{*}{ Urban population (\% of total population) } & $0.376^{* * *}$ & 0.092 & 0.553 & -0.019 & $0.374 * * *$ & 0.082 & $0.621 * * *$ & 0.195 & $0.957^{* * *}$ & 0.046 \\
\hline & $(0.07)$ & $(0.14)$ & $(0.64)$ & $(1.51)$ & $(0.15)$ & $(0.22)$ & $(0.15)$ & $(0.65)$ & $(0.32)$ & $(0.72)$ \\
\hline \multirow[t]{2}{*}{ Openness to international trade $((X+M) / G D P)(\%)$} & $0.068^{* *}$ & 0.061 & -0.006 & -0.092 & 0.095 & 0.037 & $0.168 * * *$ & 0.062 & -0.075 & -0.142 \\
\hline & $(0.03)$ & $(0.05)$ & $(0.12)$ & $(0.22)$ & $(0.06)$ & $(0.08)$ & $(0.07)$ & $(0.24)$ & $(0.07)$ & $(0.09)$ \\
\hline \multirow[t]{2}{*}{ Ratio of political and civil liberties ( 0.18 to 1.00 ) } & 2.304 & 0.324 & $-11.98 *$ & -17.471 & 2.940 & -5.314 & $9.205^{* *}$ & 6.999 & $4.618^{* *}$ & 7.372 \\
\hline & $(2.94)$ & $(3.51)$ & $(6.70)$ & $(13.51)$ & $(4.94)$ & $(4.86)$ & $(4.34)$ & (11.44) & $(2.16)$ & $(4.40)$ \\
\hline \multirow[t]{2}{*}{ Remittances (\% of GDP) } & -0.102 & -0.570 & 0.220 & 2.461 & -0.111 & -0.701 & -0.102 & 3.545 & -0.368 & $3.324^{* *}$ \\
\hline & $(0.10)$ & $(0.83)$ & $(0.53)$ & $(2.84)$ & $(0.24)$ & $(1.32)$ & $(0.26)$ & $(2.92)$ & $(0.26)$ & $(1.47)$ \\
\hline \multirow[t]{2}{*}{ Gross domestic savings (\% of GDP) } & 0.021 & -0.014 & 0.143 & 0.017 & -0.049 & -0.035 & -0.050 & 0.002 & $0.125^{*}$ & -0.250 \\
\hline & $(0.07)$ & $(0.12)$ & $(0.16)$ & $(0.31)$ & $(0.17)$ & $(0.20)$ & $(0.21)$ & $(0.31)$ & $(0.07)$ & $(0.22)$ \\
\hline \multirow[t]{2}{*}{ General gov final consumption exp (\% of GDP) } & $0.701^{* * *}$ & $0.703^{* * *}$ & -0.042 & -0.241 & $0.742^{* * *}$ & $0.593 * * *$ & $0.827^{* * *}$ & $1.296 * * *$ & $-1.570 * * *$ & $-2.747 * * *$ \\
\hline & $(0.16)$ & $(0.12)$ & $(0.44)$ & $(0.74)$ & $(0.27)$ & $(0.25)$ & $(0.32)$ & $(0.49)$ & $(0.39)$ & $(0.66)$ \\
\hline \multirow[t]{2}{*}{ Inflation rate (\%) } & $-0.097^{*}$ & $-0.098^{*}$ & -0.143 & -0.172 & -0.015 & 0.017 & -0.132 & -0.329 & -0.060 & -0.110 \\
\hline & $(0.05)$ & $(0.06)$ & $(0.10)$ & $(0.19)$ & $(0.10)$ & $(0.12)$ & $(0.12)$ & $(0.45)$ & $(0.10)$ & $(0.09)$ \\
\hline \multirow[t]{2}{*}{ Internet users (per 100 people) } & -0.012 & 0.021 & 0.010 & -0.096 & -0.003 & 0.001 & -0.063 & -0.091 & 0.046 & $0.177^{*}$ \\
\hline & $(0.03)$ & $(0.03)$ & $(0.12)$ & $(0.22)$ & $(0.06)$ & $(0.07)$ & $(0.05)$ & $(0.21)$ & $(0.11)$ & $(0.10)$ \\
\hline
\end{tabular}




\begin{tabular}{|c|c|c|c|c|c|c|c|c|c|c|}
\hline Observations & 71 & 51 & 71 & 51 & 71 & 51 & 66 & 47 & 42 & 28 \\
\hline Adj $R^{2}$ & 0.84 & 0.83 & 0.71 & 0.67 & 0.58 & 0.57 & 0.82 & 0.74 & - & - \\
\hline
\end{tabular}

All regressions include an intercept term (not shown in table)

Meaning of range of GINI coefficient: from 0 (complete equality) to 100 (complete inequality)

Meaning of range of ratio of political and civil liberties: from 0.18 (most free) to 1.00 (least free)

GMM specifications include a one-period lagged dependent variable as regressor (not shown in table)

Standard errors in parentheses

${ }^{*}$ significant at $10 \% ;{ }^{* *}$ significant at $5 \% ;{ }^{* * *}$ significant at $1 \%$ 
Table 6: Fiscal Decentralization and Income Distribution

Dependent variable: GINI Coefficient

American countries excluding Canada and the US

\begin{tabular}{|c|c|c|c|c|c|c|c|c|c|c|}
\hline \multirow[b]{2}{*}{ Revenue decentralization (\%) } & \multicolumn{2}{|c|}{$\begin{array}{l}\text { GLS accounting for } \\
\text { cross-section and within } \\
\text { a given cross-section } \\
\text { HT, AC (no effects } \\
\text { specification) }\end{array}$} & \multicolumn{2}{|c|}{$\begin{array}{l}\text { GLS with fixed, cross- } \\
\text { section effects and no } \\
\text { weights }\end{array}$} & \multicolumn{2}{|c|}{$\begin{array}{l}\text { GLS with random, } \\
\text { cross-section effects } \\
\text { and no weights }\end{array}$} & \multicolumn{2}{|c|}{$\begin{array}{l}\text { IV accounting for } \\
\text { cross-section and } \\
\text { within a given cross- } \\
\text { section HT, AC (no } \\
\text { effects specification) }\end{array}$} & \multicolumn{2}{|c|}{$\begin{array}{l}\text { Generalized Method of } \\
\text { Moments }\end{array}$} \\
\hline & 0.043 & & -0.049 & & 0.050 & & 0.522 & & 0.033 & \\
\hline & $(0.03)$ & & $(0.16)$ & & $(0.07)$ & & $(0.50)$ & & $(0.11)$ & \\
\hline \multirow[t]{2}{*}{ Expenditure decentralization (\%) } & & $0.152 * *$ & & 0.324 & & $0.189^{*}$ & & 1.858 & & -0.134 \\
\hline & & $(0.06)$ & & $(0.37)$ & & (0.09) & & $(3.98)$ & & $(0.21)$ \\
\hline \multirow[t]{2}{*}{ GDP per capita (at PPP, in logs) } & -17.334 & 29.891 & 40.043 & 102.895 & -53.160 & 61.530 & -80.795 & 361.354 & -38.130 & $96.055^{* *}$ \\
\hline & (21.14) & (38.57) & $(100.72)$ & $(206.76)$ & $(53.87)$ & (95.78) & $(190.83)$ & $(1094.03)$ & (59.31) & $(42.68)$ \\
\hline \multirow[t]{2}{*}{ GDP per capita squared (at PPP, in logs) } & 0.729 & -2.383 & -2.603 & -5.255 & 2.783 & -4.371 & 7.631 & -31.570 & 0.939 & $-6.172^{* *}$ \\
\hline & $(1.23)$ & $(2.27)$ & (5.43) & $(11.81)$ & (3.09) & (5.55) & (10.99) & (85.02) & (3.23) & (2.29) \\
\hline \multirow[t]{2}{*}{ Urban population (\% of total population) } & $0.178^{* *}$ & $0.342 * *$ & 0.386 & 0.041 & 0.213 & 0.454 & 0.260 & 10.996 & $0.957^{* * *}$ & 0.046 \\
\hline & $(0.07)$ & $(0.15)$ & $(0.65)$ & (1.55) & $(0.16)$ & $(0.31)$ & $(0.87)$ & (24.79) & $(0.32)$ & $(0.72)$ \\
\hline \multirow[t]{2}{*}{ Openness to international trade $((X+M) / G D P)(\%)$} & $0.051^{*}$ & $0.169 * * *$ & -0.033 & -0.150 & 0.079 & $0.211^{*}$ & 0.660 & 3.772 & -0.075 & -0.142 \\
\hline & $(0.03)$ & $(0.06)$ & $(0.12)$ & $(0.23)$ & $(0.06)$ & $(0.11)$ & $(0.59)$ & $(8.41)$ & $(0.07)$ & $(0.09)$ \\
\hline \multirow[t]{2}{*}{ Ratio of political and civil liberties ( 0.18 to 1.00 ) } & -3.584 & 1.374 & $-15.930 * *$ & -18.688 & -1.527 & -2.610 & 27.387 & 56.841 & $4.618^{* *}$ & 7.372 \\
\hline & $(2.40)$ & $(3.50)$ & $(7.16)$ & $(14.04)$ & $(4.84)$ & $(5.66)$ & $(27.65)$ & $(120.69)$ & $(2.16)$ & $(4.40)$ \\
\hline \multirow[t]{2}{*}{ Remittances (\% of GDP) } & -0.067 & -1.166 & 0.010 & 1.397 & -0.083 & -1.312 & -0.258 & -19.527 & -0.368 & $3.324 * *$ \\
\hline & $(0.09)$ & $(0.83)$ & $(0.55)$ & $(3.01)$ & $(0.21)$ & $(1.37)$ & $(0.96)$ & $(62.20)$ & $(0.26)$ & (1.47) \\
\hline \multirow[t]{2}{*}{ Gross domestic savings (\% of GDP) } & $0.120 * *$ & 0.011 & 0.149 & 0.111 & 0.055 & -0.070 & 0.555 & -1.904 & $0.125^{*}$ & -0.251 \\
\hline & $(0.06)$ & $(0.10)$ & $(0.16)$ & $(0.33)$ & $(0.15)$ & $(0.21)$ & $(0.88)$ & $(5.23)$ & $(0.07)$ & $(0.22)$ \\
\hline \multirow[t]{3}{*}{ General gov final consumption exp (\% of GDP) } & $0.684^{* * *}$ & $0.859 * * *$ & 0.192 & 0.047 & $0.746^{* * *}$ & $0.852^{* * *}$ & 2.948 & 2.088 & $-1.570 * * *$ & $-2.747^{* * *}$ \\
\hline & $(0.16)$ & $(0.15)$ & $(0.46)$ & $(0.78)$ & $(0.24)$ & $(0.26)$ & $(2.70)$ & $(2.56)$ & (0.39) & $(0.66)$ \\
\hline & - & & & & & & & & & \\
\hline \multirow[t]{3}{*}{ Inflation rate (\%) } & $0.202^{* * *}$ & $-0.160 * *$ & -0.141 & -0.162 & -0.148 & -0.050 & -4.636 & 1.195 & -0.060 & -0.110 \\
\hline & $(0.05)$ & $(0.07)$ & $(0.10)$ & $(0.19)$ & $(0.10)$ & $(0.12)$ & $(4.41)$ & $(4.72)$ & $(0.10)$ & $(0.09)$ \\
\hline & - & & & & & & & & & \\
\hline Internet users (per 100 people) & $0.165^{* * *}$ & -0.032 & -0.147 & -0.273 & $-0.185^{* *}$ & 0.005 & -2.039 & 1.030 & 0.046 & $0.177^{*}$ \\
\hline
\end{tabular}




\begin{tabular}{|c|c|c|c|c|c|c|c|c|c|c|}
\hline & $(0.04)$ & $(0.07)$ & $(0.16)$ & $(0.27)$ & $(0.09)$ & $(0.11)$ & (1.81) & (3.13) & $(0.11)$ & (0.10) \\
\hline Observations & 67 & 46 & 67 & 46 & 67 & 46 & 62 & 42 & 42 & 28 \\
\hline Adj $R^{2}$ & 0.88 & 0.72 & 0.60 & 0.40 & 0.45 & 0.32 & - & - & - & - \\
\hline
\end{tabular}

All regressions include an intercept term (not shown in table)

Meaning of range of GINI coefficient: from 0 (complete equality) to 100 (complete inequality)

Meaning of range of ratio of political and civil liberties: from 0.18 (most free) to 1.00 (least free)

GMM specifications include a one-period lagged dependent variable as regressor (not shown in table)

Standard errors in parentheses

*significant at $10 \%$; ${ }^{*}$ significant at $5 \% ;{ }^{* * *}$ significant at $1 \%$ 